\title{
THE UNDERSTANDING OF BMT'S PRACTITIONERS OF THE PSAK NO. 59 (THE ACCOUNTING OF SHARI' AH BANKING) ON THE RECOGNITION AND MEASUREMENT OF FUNDING PRODUCTS
}

\author{
By: Eny Iroh Hayati*
}

\begin{abstract}
The objective of this research is to explore BMT practitioners' understanding of the SPAK No. 59 on the Accounting of Shari'ah Banking for funding products. For this reason, the research is conducted by descriptive method. Field research using quantitative approach is also used. However, qualitative approach is also used to explore and to clarify as well as to compare between the concept and the real situation. The population used in this study are members of PUSKOPSYAH DIY, and the subjects of this research are the managers and accounting staffs of these BMTs. The sample consists of $30 \%$ of 80 active members. However, since the magnitude of each sub-population is different, proportional sampling method is used to determine the number of sample taken from each sub-population, and purposive sampling method is used as the sampling method. The independent variables used in this research are age, educational background, length of time working in BMT, and frequency of training or workshop joined by the subjects. Meanwhile, the dependent variable in this research is the BMT practitioners' understanding about SPAK No. 59 for funding product. Data gathering methods used in this research were questionnaire, field observation and interview. Meanwhile, data analyses for this study include descriptive statistical analysis and inferential statistical analysis.
\end{abstract}

Keywords: accounting, PSAK No. 59, understanding, practitioners of BMT

\section{A. Introduction}

The emergence of alternative shari'ah financial institutions was caused by the difficulties of shari'ah banking in reaching grassroots levels. Their commitment to enhance the condition of grassroots communities faces many obstacles from either in the regulations or practice. Legally and technically, the loan procedures of conventional bank and the BPRS are similar. In fact, the loan procedure is the main hindrance for small entrepreneurs to bring the hope of shari'ah banking into reality.

\footnotetext{
* The author is an alumnus of Islamic Study Master Program on Islamic Economy at Indonesian Islamic University. Email: enys_uin@yahoo.com
} 
The BMT (Baitul Mâl wat-Tamwîl) as one of the alternative shari'ah financial institutions is both a business and social oriented institution ${ }^{1}$. The BMT is a micro financial institution which operates in low level communities. By employing shari'ah principles, this institution is not merely controlled by economic aspects and society; instead religion or theology is more dominant in control.

In the end of 2005 total number of BMTs (Baitul Mal wat-Tamwil) in Indonesia reached 3.000 units. ${ }^{2}$ While in Daerah Istimewa Yogyakarta, according to PUSKOPSYAH data, until August 2006 the total number of BMTs were 82 units, $^{3}$ excluded the BMTs outside the PUSKOPSYAH members.

Even though the emergence of many BMTs in this country is a good phenomenon, it doesn't mean its development is going on smoothly. There are many crucial problems need to be solved. One of the problems concerns about the implementation of Islamic shari'ah principles on accounting. The accounting in a financial institution is a vital aspect because every financial institution always connected to financial transactions which need a guideline. Consequently, accounting is necessary so that every economic transaction in the institution is well documented and controlled. By way of accounting, the rights of every party will be fairly protected. $^{4}$

Legally and formally, the BMT has the same legal entity with the cooperation. However, the BMT's standards of accounting are varied. ${ }^{5}$ Some of the BMTs apply cooperation accounting, limited company accounting, and even the standard of banking accounting. Because the BMT basically is the cooperation in its legal entity, it adopts Pernyataan Standar Akuntansi Keuangan (PSAK)/ The Standard Record for

\footnotetext{
${ }^{1}$ Muhammad Ridwan, Manajemen Baitul Mal wat Tamwil, (Yogyakarta: UII Press. 2004), p. 73-74.

${ }^{2}$ Quoted from www.republika.co.id, accessed in 2006.

${ }^{3}$ Source: Puskopsyah DIY

${ }^{4}$ Hertanto Widodo et al., Pedoman Akuntansi Syariat Panduan Praktis Operasional Baitul Mal Wat Tamwil, (Bandung: Mizan, 2000), p 58.

5 "BMT Perlu Standard Akuntansi" quoted from www.republika.co.id, accessed on April 5, 2006.
} 
Financial Accounting No. 27 about the Cooperation Accounting as its standard of accounting. In this case, Triyuwono said that the social oriented of the cooperation has colored its practice or cooperation financial accounting. ${ }^{6}$ However, even though the accounting is within a social nuance of the cooperation, it is more influenced by its capitalist origin (gives the priority to its members over anybody else, which contrast with the characteristics of shari'ah financial systems).

Moreover, Amin Aziz, the chairperson of Pusat Inkubasi Usaha Kecil (PINBUK), admits that the BMT's operating method is closed to that of the conventional bank instead of the cooperation. While the cooperation operates only in money saving and loan for its members, the BMT also serves people other than its member. ${ }^{7}$ Yaya shares this idea. ${ }^{8}$ He states that as an institution which based on Islamic values, the BMT and shari'ah banking operate on the basis of fiqh. The BMT and shari'ah banking operation should be based on fatwas from Dewan Syari'ah Nasional (DSN)/ The Shari'ah National Board which is authorized to determine the legal basis of any transaction. Consequently, in practice, there is no difference between the transaction in the BMT and shari'ah banking.

The BMT and shari'ah banking are substantively similar because they operate in similar systems. Therefore it would not be insufficient if the BMT uses the standard accounting of the PSAK No. 27. It would be adequate if BMT uses the PSAK No. 59 on the Accounting of Shari'ah Banking. As mentioned by Adian, even though the formal concept of accounting for shari'ah micro financial institutions has

\footnotetext{
${ }^{6}$ Iwan Triyuwono, “Akuntansi Syari'ah dan Koperasi Mencari Bentuk Dalam Metafora Amanah”, Jurnal Akuntansi dan Auditing Indonesia, Volume 1 No.1 May 1997, pp. 38-42.

7 Amin Aziz in "Jangan Paksa BMT Besar Jadi BPRS" quoted from www. republika.co.id, accessed on April 5, 2006.

${ }^{8}$ Rizal Yaya, "Mengkritisi Konsep Akuntansi Keuangan bagi Lembaga Keuangan Mikro Syari'ah". Workshop Merancang Format Akuntansi Keuangan Bagi Lembaga Keuangan Mikro Syariah at Hotel Inna Garuda-Yogyakarta on August 9-12, 2004 held by Pusat Pengembangan Ekonomi (PPE)/Center for Economic Development of Muhammadiyah Univesity of Yogyakarta and BMT Hidayatul Muamalah Wonogiri, pp. 7-8.
} 
not been composed, normatively these institutions may refer to the PSAK No. 59 and the basic framework for the arrangement and presentation of financial reports. ${ }^{9}$

The object of this research is not merely a problem in the practical level but also the problem of following the rule of shari'ah for shari'ah financial institutions, especially the BMT in Yogyakarta. Based on the phenomenon mention above, it is necessary to conduct further research concerning the understanding of the BMT's practitioners towards the PSAK No. 59 of the Accounting of Shari'ah Banking, the recognition and measurement of funding products, and the relationships between age, working term in the BMT, educational background and frequency of participating in training, seminar, and such activities, and the understanding of the BMT's practitioners on the PSAK No. 59 on the recognition and measurement of funding products. The understanding of the BMT's practitioners (mainly the managers and the accountants), will affect the policy and the technical accounting used by the BMT. Consequently, this research will serve as the starting point to find out the understanding of the BMT's practitioners in Yogyakarta on the PSAK No. 59 and its possible application.

Based on the problems mentioned above, this article will attempt to describe how the BMT's practitioners in Yogyakarta comprehend Pernyataan Standar Akuntansi Keuangan (PSAK / the Standard Record for Financial Accounting) No. 59 on the acknowledgment and measurement of funding products, and also to find out the connections between age, working term in the BMT, educational background and frequency of training, seminar or other form of trainings, and the understanding of the BMT's practitioners on the concepts of the acknowledgement and measurement of funding products.

9 Akhyar Adnan, "Kritik atas Konsep Akuntansi Keuangan Lembaga Syariah Mikro" in Workshop Merancang Format Akuntansi Keuangan Bagi Lembaga Keuangan Mikro Syariah at Hotel Inna Garuda-Yogyakarta on August 9-12, 2004 held by Pusat Pengembangan Ekonomi (PPE)/ Center for Economic Development of Muhammadiyah University of Yogyakarta and BMT Hidayatul Muamalah Wonogiri, p. 10. 


\section{B. Bibliographical Research}

Islam as an ideology is full of values. Consequently, the accounting operation in the Islamic communities has to adjust with Islamic characteristic. Islamic teaching should be applicable as the basis for the whole aspect in the community. ${ }^{10}$

Generally, accounting could be defined as the system of information to make a report to anyone who may concern about the economic activity and business' state. ${ }^{11}$ Theoretically, there are several definitions of accounting. According to the American Institute of Certified Public Accountant (AICPA), accounting is the art of documenting, grouping, and abridging in a certain way and in monetary measurements of transactions and financial occasions, and also interpreting the results.

The accounting aims at providing information to the user as the basis of decision making. The general objective of accounting is presenting the description to its users about the business performance, financial condition, and cash flow of an institution in a period of time. Based on this universal objective, the information of accounting can be used for special purpose, such as to count taxes and possibly, to count zakat.

Accounting is one of "muamalah" domains in Islamic teaching. It means that its development depends on human reason. However, for accounting is significant, Allah gives a special consideration in the Qur'an as the foundation of accounting according to Islamic shari'ah, Al-Baqarah (2) $282 .{ }^{12}$ In this ayat (verse), it is clear that in Islam, taking note in a transaction (mu'amalah) is a compulsory as the foundation for the future assessment and the solution for further problem, and for the prevention from manipulation or fraud of the transaction and its profit. ${ }^{13}$ Deriving

\footnotetext{
${ }^{10}$ Muhamad, Pengantar Akuntansi Syariah, (Jakarta: Salemba Empat, 2002), p.10.

11 Carl S. Warren, et. al, Accounting 21th Edition, translated by Aria Farahmita, et al. Pengantar Akuntansi Edisi 21 (Buku 1), Jakarta (Salemba Empat, 2005), pp. 24-27.

${ }^{12}$ Al-Quran dan Terjemahnya, Depag RI.

${ }^{13}$ Sofyan Syafri Harahap, Akuntansi Islam, (Jakarta: Bumi Aksara, 1997), p. 142.
} 
from this verse, Muhammad mentioned three general principles of shariah accounting; responsibility, justice and righteousness. ${ }^{14}$

In Accounting Issues in Islamic Banking, ${ }^{15}$ as quoted by Muhammad, it is mentioned that the goal of accounting information in shari'ah financial institutions emerges because two reasons:

1. Shari'ah Financial Institutions are managed within the framework of shari'ah since essentially its transaction is different from that of conventional financial institutions.

2. The users of accounting information of shari'ah financial institutions are different from that of conventional financial institutions.

The result of the accounting cycle is the availability of financial reports. A high quality financial report should accomplish the qualitative requirements of financial reports i.e. understandable, reliable, relevant and comparable. If a public business records and reports its financial data using its own standard, it would be difficult or even possible to compare this business to the similar one. ${ }^{16}$ Therefore, the practice of accounting in accordance with the general standard of accounting is necessary ${ }^{17}$, whereas in other aspects the standard is not necessary. In Indonesia, the law to measure/ justify, manage and communicate the accounting information is available at SAK (Standar Akutansi Keuangan)/ the Standard for Financial Accounting which deals with the common accounting principles. While on more specific aspects of accounting there is the PSAK. ${ }^{18}$

Regarding the standard of accounting, Edey, as quoted by Muhammad, stated that the standard is meant: ${ }^{19}$

${ }^{14}$ Muhammad, Prinsip-prinsip Akuntansi dalam Al-Qur'an, (Yogyakarta: UII Press, 2000) p. 42.

15 "Institute of Islamic Banking and Insurance, Accounting Issues in Islamic Banking", in Muhamad, Pengantar..., p. 103.

${ }^{16}$ Carl S. Warren, Accounting..., p. 16.

${ }^{17}$ Mursyidi, Akuntansi Zakat Kontemporer, (Bandung: Remaja Rosda Karya, 2003), p. 14.

${ }^{18}$ Charles T. Horngren, Accounting.., p. 7.

${ }^{19}$ Edey in Muhamad, Pengantar Akuntansi Syari'ah, $2^{\text {nd }}$ edition, (Jakarta: Salemba Empat, 2005), p. 201. 
1. To oblige accountants to inform what they have done by indicating the method and strategy of accounting that are being used.

2. To support the uniformity in the presentations of financial report.

3. To support the exposure of specific aspects that might be needed by the users of the information as the basic for their decision makings.

4. To stipulate the disclosure of explicit and implicit decisions about the accepted assessment of assets and profit arrangement.

The standard of accounting according to the general standard of accounting is necessary in the business world. ${ }^{20}$ The PSAK No. 59 on the accounting of shari'ah banking, legalized by Dewan Standar Akuntansi Keuangan (The Board for the Standardization of Financial Accounting) on May 1, 2002, is one of discourse on the practice of shari'ah accounting in Indonesia. Shari'ah accounting, by means of the PSAK No. 59, does not only provide information for the process of decision making but also guarantee that an institution is abide by the principle and rule of shari'ah, and also by that of socio-economic. ${ }^{21}$ These are the characteristics of shari'ah financial institutions. Practical reports of shari'ah financial accounting are composed for the same users of the conventional accounting with the addition of institutional investors, zakat, infaq and shadaqah payers, and Dewan Pengawas Syari'ah (The Supervisory Board of Shari'ah).

The PSAK 59 contains the acknowledgement, measurement and characteristics of shari'ah banking products such as mudârabah, musyârakah, murâbahah, salam, istishnâ, wadîah, qardh, sharf, and the admission and

${ }^{20}$ Mursyidi, Akuntansi..., p. 14.

${ }^{21}$ Dwi Ratmono, "Pengungkapan Islamic Values Dalam Pelaporan Keuangan Bank Syariah Paradigma Akuntansi Syariah Filosofis-Teoritis dan PSAK 59", Prosiding Simposium Nasional Sistem Ekonomi Islam II, Pusat Pengkajian Bisnis dan Ekonomi Islam Fakultas Ekonomi, (Center for Business and Islamic Economics Studies, the Faculty of Economics) Brawijaya University of Malang, May 28-29, 2004, p. 395. 
measurement of zakat. It also consists of the composition of Shari'ah Banking Financial Reports and also the general presentation of Financial Report. ${ }^{22}$

From the point of view of the development of shari'ah banking and shari'ah micro financial institutions, the PSAK No. 59 may serve as an instrument to enhance public trust in money saving and doing business with shari'ah banking or shari'ah micro financial institutions. On the other hand, since Indonesian business' environment is lack of Islamic values integrity, the PSAK No. 59 is expected to be the guidance for the improvement of Islamic business as well as for the development of the science of business which regards the morality, religious spirits, and social awareness. $^{23}$ Therefore the understanding of BMT practitioners will affect the establishment of a reliable and just accounting system.

\section{Research Methodology}

This research uses the quantitative approach. However, the use of qualitative approach is unavoidable in revealing and explaining about the concept and reality. This approach may also be applied in revealing the problems of shari'ah accounting in shari'ah micro financial institutions. This is a field research that is carried out by doing observation and interview with the BMT's managers and accounting staffs, as the research sample, to represent and describe all of the BMTs in Yogyakarta. This field research intends to find out common inclinations related to the operational techniques of shari'ah accounting (the PSAK No. 59) at the BMTs in Yogyakarta.

This research can be classified as a descriptive research because the intention of this research is to describe the understanding of the BMT's practitioners about the PSAK No. 59 on the admission and measurement of funding products. Moreover, this research also tries to portray the correlation between variables or to illustrate the relations between two or more quantitative variables shown by the coefficient of

22 See "Pernyataan Standar Akuntansi Keuangan No 59 Ikatan Akuntan Indonesia", $1^{\text {st }}$ Edition, May 2002, $1^{\text {st }}$ paragraph.

${ }^{23}$ Dwi Ratmono, "Pengungkapan..., p. 395. 
correlation numbers. ${ }^{24}$ The population of this research is the BMTs which are the members of the PUSKOPYAH in Daerah Istimewa Yogyakarta (Special Province of Yogyakarta). According to data from the PUSKOPYAH, on August 31, 2006 there were 80 active BMTs which were the members of the PUSKOPYAH BMT Mitra Nugraha, from all five regencies in Yogyakarta Province. According to Gay, as quoted by Husein Umar, ${ }^{25}$ the minimum of the acceptable sample based on its descriptive design is $10 \%$ of population, or $20 \%$ for small population. This research will take $30 \%$ of the population.

The technique of sample taking of this research is proportional sampling. Subsequently, simple random sampling is used to decide which BMT will be chosen as sample at each subpopulation, while purposive sampling is employed to choose the respondents to fill in questionnaires. The respondents are the BMT's practitioners i.e. the managers and the accounting staffs of the BMT.

The research variables of this research are: Independent Variables, symbolized by X, consist of: age (), educational background (); working term in BMT (); and frequency of training, seminar and such other activities (). While Dependent Variable, symbolized by Y, is the understanding of the BMT's practitioner on the PSAK No. 59 about the recognition and measurement of funding products.

As this is a field research which is naturally descriptive, the data is collected by means of questionnaires, observations, and interviews. Subsequently, data is analyzed in several steps: data processing stage which includes data editing and data coding, data analysis stage, and data interpretation stage.

The data analysis refers to the activity of organizing data into certain structures in order to be interpreted. In this research the data analysis consist of descriptive statistic analysis and inferential statistic analysis. ${ }^{26}$ The descriptive statistic analysis is used to analyze data by describing or portraying data collected

${ }^{24}$ Soehardi Sigit, Pengantar Metodologi Penelitian Sosial Bisnis Manajemen, (Yogyakarta: Lukman Offset, 1999), p. 99.

${ }^{25}$ Husein Umar, Riset Akuntansi, (Jakarta: Gramedia Pustaka Utama, 1998), p.70.

${ }^{26}$ Sugiyono, Metode Penelitian Administrasi, $13{ }^{\text {th }}$ Edition, (Bandung: Alfabeta, 2005), p. 169. 
from questionnaires, tabulating, and calculating the percentages. This analysis uses to address the first problem, while inferential statistic analysis is applied for the measurement of the connection level between the variables.

In dealing with the correlations between more than two variables, the technique of statistic employed is the multiple correlations analysis in which the result is the coefficient of multiple correlations $(\mathrm{R})$, and the partial correlation analysis which results the coefficient of partial correlation (). ${ }^{27}$ The $\mathrm{F}$ test is applied for the test of the coefficient of multiple correlations and the t test is applied for the test of the coefficient of partial correlation. ${ }^{28}$ Basically, the F test is test on $\mathrm{R}$, (the coefficient of multiple correlations). ${ }^{29}$ In other word F test is applied for the test on the significance of $\mathrm{R}$.

\section{Analysis}

Of the answers from the respondents of the questionnaires, most respondents (95.8\%) have deep understanding on the subject. This result might be caused by the fact that basically, funding products which consist of mudarabah and wadiah savings are quite known. However, there are several points need to be observed. Based on their answers, even though the level of the understanding of the BMT's practitioners on the PSAK No. 59 is quite high, $95.8 \%$, only $62.5 \%$ of them are agree that the standard accounting suitable for the BMTs is the PSAK No. 59, the rest are disagree with this opinion. This is interesting because in one hand they have sufficient understanding of the PSAK No. 59 but in the other hand they do not entirely agree with its application. This might be caused by the lack of socialization of the PSAK No. 59 to the BMT's managements. Consequently, even though the BMT's practitioners are well informed about the PSAK No. 59, the BMT's managements are

${ }^{27}$ Husaini Usman and R. Purnomo Setiady Akbar, Pengantar Statistika, (Jakarta: Bumi Aksara, 1995), p. 253.

${ }^{28}$ Iqbal Hasan, Analisa Data Penelitian Dengan Statistik, (Jakarta: Bumi Aksara, 2005), (Jakarta: Bumi Aksara, 2005), p. 80.

${ }^{29}$ Sanapiah Faisal, Format-format Penelitian Sosial, (Jakarta: Raja Grafindo Persada, 2005), pp. 235-237. 
reluctant to implement it in their institutions since they do not have political will in its implementation and besides there is no precise instrument for the application of the PSAK No. 59 in the BMTs. This situation portrays that the implementation of the PSAK No. 59 is a long going process.

Since it is already noticed that the respondents have high level of understanding of the subject, the next question will be whether the age, working term, educational background, and frequency of following trainings, relate to the degree of respondents understanding about the PSAK No. 59 on the acknowledgment and measurement of funding products. The result will be very interesting to be studied, because based on the observation and interview on respondents, 75\% of the BMT's managements have not applied the PSAK No. 59 in their institutions yet.

The result of the multiple correlations analysis is the coefficient of multiple correlations $(\mathrm{R})$ approximately 0.682 . The interpretation of the value $\mathrm{R}$ is that independent variables consist of age, working term, educational background, and frequency of trainings, altogether have a sufficient relationship ${ }^{30}$ to the dependent variable (the understanding of respondents on PSAK No. 59 about the admission and measurement of funding products). Of significance level 5\% and degree free (df) 43 the result is 2.589 . Thus, it can be concluded that independent variables altogether has a significant relationship with the dependent variable.

On the other hand, the result of the partial correlation analysis of this research shows that the variable of educational background is the closest variable to the variable of understanding. This significant relationship is shown by the coefficient number of partial correlation about 0.491 . Followed by the variable of age around 0.361 , variable of working term approximately 0.326 , and the last is the less close connection variable that is frequency of trainings about 0.319 .

The variable of educational background is proven to have the closer connection to that of other variables. The $t$ test shows that the variable of educational

\footnotetext{
${ }^{30}$ See Husaini Usman and R. Purnomo Setiady Akbar, Pengantar, p. 253
} 
background has significant connection to the understanding of the BMT's practitioners about the PSAK No.59 on the Accounting of Shari'ah Banking on the recognition and measurement of funding products, although the correlation is lesser. The correlation between educational background and the understanding is feasible since according to the frequency of distribution, approximately $58.3 \%$ of respondents have educational background in economy. The related educational background will ease respondents in studying and understanding the terms used in the PSAK No. 59, especially if the respondents are in the productive age (20 to 30 years old), and have a long working term and frequently joining the trainings. In another word, if the respondents are lack of knowledge and basic skill (their educational background is not adequate for the job), it will create difficulties in understanding the content of substances. Subsequently, the quantity and quality of the absorption of content (understanding) are far from the expectation.

The cross-tabs between the variable of educational background and the variable of the degree of understanding shows that there are no respondents with the low level of understanding and only $4.2 \%$ of respondents are in the middle level. The respondents with educational background of undergraduate (S1), diploma (D3) and graduate (S2) altogether have a high level of understanding on the PSAK No. 59 about the admission and measurement of funding products. Among respondents with educational background of high school, $86.9 \%$ of them have a high level of understanding while $13.4 \%$ are in the middle level of understanding.

The variable of age also related to the understanding of the BMT's practitioners about the PSAK No. 59 on the recognition and measurement of funding products. The result of the t test demonstrates that the variable of age has a significant correlation with the understanding of the BMT's practitioners on the PSAK No. 59 on the Accounting of Shari'ah Banking about the recognition and measurement of funding products, although in very low stage. From the frequency of distribution it is clear that the majority of respondents are in the 20 to 30 age group (52.1\%) and in the 31 to 40 age group $(41.7 \%)$. The cross-tabs between the variable of age and 
understanding stages show that in the 20 to 30 age group, approximately $91.9 \%$ of respondents are in the high stage of understanding and $8.1 \%$ of them are in the middle level of understanding. The other group of age demonstrates that all respondents have a high level of understanding.

The high degree of understanding of respondents of the 20 to 30 age group, the productive age, is an interesting phenomenon. Based on their age, human's intellectuality is increasing and reached its peak point in the age of 20 to 30 . In the age between 30 to 60 years human's intellectuality is decreasing and it is decreasing sharply after the age of $60 .{ }^{31}$ In the age between 20 until 30 years, people are in the height of their physiological condition. This physiological aspect consists of general physical condition and tonus (muscle tone) which reveal the healthiness of organs and its joints. These aspects affect people spirit and intensity in learning.

The old age or the early age may reduce the cognitive quality of people to learn, so it is difficult to absorb learning material or even impossible this age. Moreover, as people age, their hearing gets worse. At their 20s, people are able to hear a voice from the distance of 8 to 10 meters. However, at their 40s, people are not able to hear a voice from more than 5 meters distance. ${ }^{32}$

Other variables relate to the degree of understanding is the variable of working term in the BMT. Using the $t$ test, the result shows that the variable of working term has a significant correlation with the understanding of the BMT's practitioners about the PSAK No. 59 on the recognition and measurement of funding products even though it is in a low level. Moreover, the questionnaires portray that the respondents with working term in the BMT around 3 until 5 years are approximately $31.3 \%$ while those who have been working for 1 until 3 years are also around 31.3\%. Respondents with 5 to 7 years working term are 10 people or approximately $20.8 \%$ whereas those who are working for more than 7 years are about $16.7 \%$.

${ }^{31}$ Rosjidan, dkk, Belajar dan Pembelajaran, (Malang: FIP Universitas Negeri Malang, 2001), p. 12 .

\footnotetext{
${ }^{32}$ Ibid., p. 10.
} 
The cross-tabs between the variable of working term and the degree of understanding do not show any respondent with low level of understanding. In the group of people who work less than 3 years, $86.6 \%$ of them are in the high level of understanding while $13.4 \%$ are in the middle stage. The rest of respondents are in the high stage of understanding.

The level of understanding of respondents with 3 to 5 years of working term indicates that basically respondents are familiar with the basics theory and practice of the recognition and measurement of funding products. Thus, respondents with long working term in the BMT will be able to figure out their job although their age is beyond the productive age or with insufficient educational background.

Another variable relates to the height of understanding is the frequency of training and seminar. The $t$ test on the coefficient of partial correlation demonstrates the significance of the frequency of training towards the degree of understanding of the BMT's practitioners about the PSAK No. 59 on the Accounting of Shari'ah Banking on the acknowledgment and measurement of funding products, although in a low level.

The frequency distribution depicts that about $43.8 \%$ of respondents are joining trainings around 1 until 3 times. Approximately 33.3\% of respondents join workshops for 4 up to 6 times. Respondents who join 7 to 9 times are around $10.4 \%$ and those who join trainings more than 9 times are approximately $12.5 \%$. If the frequency of training is connected to the degree of understanding, respondents with 1 to 3 times training, approximately $9.6 \%$ of respondents who join 1 to 3 times training are in the middle level of understanding while around $90.4 \%$ are in the high stage. The other groups are in the high stage of understanding.

Interest and motivation are one of psychological factors that affect the quality and quantity of human learning ability. ${ }^{33}$ Subsequently, the frequency of joining seminar and training will broaden the knowledge and understanding (material

\section{${ }^{33}$ Ibid.}


mastering) of the BMT's practitioners on the PSAK No. 59. In addition, the interview with respondents confirms that the understanding of the PSAK No. 59 is mostly gained through trainings and seminars.

\section{E. Conclusion}

The respondents, who are the BMT's practitioners and members of the PUSKOPSYAH of Daerah Istimewa Yogyakarta, i.e. managers and its accounting staffs, generally have the high level of understanding on the PSAK No. 59 on the recognition and measurement of funding products. The questionnaires show that approximately $95.8 \%$ of respondents are in the high stage of understanding, while the rest $4.2 \%$ is on the middle level category.

Based on the result of the relation analysis test, the independent and dependent variables are related to the understanding of respondents on the PSAK No. 59 about the recognition and measurement of funding products $(\mathrm{R}=0.682)$. On the other hand, the statistic test of the coefficient of multiple correlations explains that all independent variables in this research, altogether, have significant correlation with the dependent variable. While the partial correlation analysis verifies that independent variables which have the closest relations to the understanding are, in sequence, educational background, age, working term and frequency of training.

\section{BIBLIOGRAPHY}

Adnan, Akhyar. "Kritik atas Konsep Akuntansi Keuangan Lembaga Syari' ah Mikro". Workshop Merancang Format Akuntansi Keuangan Bagi Lembaga Keuangan Mikro Syariah at Hotel Inna Garuda-Yogyakarta on 9-12 August 2004 held by Pusat Pengembangan Ekonomi (PPE) Universitas Muhammadiyah Yogyakarta and BMT Hidayatul Muamalah Wonogiri.

Faisal, Sanapiah. 2005. Format-format Penelitian Sosial. Jakarta: Radja Grafindo Persada.

Harahap, Sofyan Syafri. 1999. Akuntansi Islam. Jakarta: Bumi Aksara.

Hasan, Iqbal. 2005. Analisa Data Penelitian Dengan Statistik. Jakarta: Bumi Aksara. 
Horngren, Charles T. 1996. “Accounting 3th Edition”. Translated by Thomas H. Secokusumo. Pengantar Akuntansi (Buku 1). Jakarta: Salemba Empat.

Ikatan Akuntan Indonesia, 2003. Pernyataan Standar Akuntansi Keuangan (PSAK) No. 59 Akuntansi Perbankan Syari'ah.

Ilmi, Makhalul. 2002. Teori dan Praktek Lembaga Mikro Keuangan Syariah. Yogyakarta: UII Press.

Institute of Islamic Banking and Insurance. 1994. Accounting Issues in Islamic Banking. London.

Muhammad. 2002. Pengantar Akuntansi Syari'ah. Jakarta: Salemba Empat.

Muhammad. 2005. Pengantar Akuntansi Syari'ah. Edition 2 (Revision). Jakarta: Salemba Empat.

Mursyidi. 2003. Akuntansi Zakat Kontemporer. Bandung: Remaja Rosdakarya.

Ratmono, Dwi. Pengungkapan Islamic Values Dalam Pelaporan Keuangan Bank Syari'ah Paradigma Akuntansi Syari'ah Filosofis Teoritis dan PSAK 59. Paper of Proceeding National Symposium on Islamic Economic System II held by Pusat Pengkajian Bisnis dan Ekonomi Islam Universitas Brawijaya Malang, 28-29 May 2004.

Rosjidan et. al. 2001. Belajar dan Pembelajaran. Malang, FIP Universitas Negeri Malang.

Sigit, Soehardi. 1999. Pengantar Metodologi Penelitian untuk Sosial Bisnis Manajemen. Yogyakarta: Lukman Offset.

Sugiyono. 2003. Metode Penelitian Administrasi. Bandung, Alfabeta.

Triyuwono, Iwan. "Akuntansi Syari'ah dan Koperasi Mencari Bentuk dalam Metafora Amanah" in Jurnal Akuntansi dan Auditing Indonesia 1: 1 (May 1997).

Triyuwono, Iwan. "Metafora Zakat dan Shari'ah Enpterpise Theory sebagai Konsep Dasar dalamMembentuk Akuntansi Syari'ah" in Jurnal Akuntansi dan Auditing Indonesia 5: 2 (December 2001).

Umar, Husein. 1998. Riset Akuntansi. Jakarta: Gramedia Pustaka Utama.

Usman, Husaini dan R. Purnomo Setiady Akbar. 1995. Pengantar Statistika. Jakarta: Bumi Aksara.

Warren, Carl S. et. al. 2005. "Accounting 21th Edition”. translated by Aria Farahmita, et. al. Pengantar Akuntansi Edisi 21. Book 1. Jakarta: Salembat Empat.

Widodo, Hertanto.2000. Pedoman Akuntansi Syariat Panduan Praktis Operasional Baitul Mal wat Tamwil. Bandung: Mizan. 
Yaya, Rizal. "Mengkritisi Konsep Akuntansi Keuangan Bagi Lembaga Keuangan Mikro Syariah". Paper presented at Workshop Merancang Format Akuntansi Keuangan Bagi Lembaga Keuangan Mikro Syariah at Hotel Inna GarudaYogyakarta on 9-12 August 2004 held by Pusat Pengembangan Ekonomi (PPE) Universitas Muhammadiyah Yogyakarta and BMT Hidayatul Muamalah Wonogiri.

www.republika.co.id. 